\title{
The Connection between Arabic and Western Cultures in the Rise of Populism
}

\author{
Fadlil Munawwar Manshur \\ Faculty of Cultural Sciences, Universitas Gadjah Mada, Indonesia \\ Email: fadlil.manshur@gmail.com
}

\begin{abstract}
This article discusses the rise of populism in Arabic and Western cultures as well as the connection between them. This study shows that populism in the Arab and Western world have several common characteristics: resistance against the mainstream, xenophobia, isolation, intolerance, hostility towards strangers, extremism, radicalism, anti-multiculturalism, and anti-globalization. The rise of populism has affected Arabic and Western cultures, as well as their interactions. Because of populism, Western culture's views of the outside world, strangers, immigrants, and Islam has changed significantly. Western culture, influenced by populism, tends to be intolerant, isolated, xenophobic, and lack trust in multiculturalism. Meanwhile, populism in Arabic culture tends to be more antiWestern, anti-capitalist, and anti-liberalist. With the rise of populism, relations between these two cultural entities have become colored by tension, distrust, suspicion, and xenophobia.
\end{abstract}

Keywords: populism; Arabic culture; Western culture; xenophobia; anti-immigrant; antimulticulturalism; anti-globalization

\section{INTRODUCTION}

In scientific studies, relations between the Arabic and Western world are usually examined from a political, economic, defense and security, or education perspective. The connection between them is also seen from the dimension of civilization, seen in the concept of "the clash of civilizations" introduced by Bernard Lewis before the collapse of the Soviet Union (Lewis, 1982; Hunter, 1998: 5) before being popularized by Samuel P. Huntington in 1993 (Huntington, 1993; 1996). There are few studies about the relations between the Arab and Western worlds from a populist perspective. In the Western world, populism has received the attention of several social and contemporary politics scholars (Mudde, 2004; Berezin, 2013; Kaltwasser, 2013); however, populism in the Arab world has yet to be widely researched. The studies examining populism in the Arab world only emphasize Islamic aspects; as such, the common terms used term is 'Islamic populism', not Arab populism. Several studies about the relationship between populism and Islam were conducted by J. White (2002), A. Colas (2004), and O. Roy (2004). A more recent study about populism and Islam was conducted by Vedi R. Hadiz $(2013,2017)$ from the Asia Research Centre, Murdoch University, Perth, Western Australia.

The lack of studies about populism in the Arab world is caused by the existence of more pressing issues, particularly radicalism, terrorism, conflict, and war. Besides that, owing to the complex, multi-faceted concept of populism, which spans varied historical periods, its theoretical framework is more complicated to use. Therefore, social scientists tend to use the "clash of civilizations' thesis to analyze the Arab-Western relations.

This has occurred because the thesis, popularized by Huntington, is considered theoretically concise and simpler. This thesis asserts that the differences between civilizations are not only real, but fundamental (Huntington, 1993: 25). Civilizations are differentiated based on their histories, cultures, languages, traditions, and especially religions. Differences in religion have led 
to the emergence of different points of view regarding the relationship between humans and God, citizen and state, rights and obligations, as well as between individuals and societies. For Huntington, the main source of conflict in contemporary society is not ideology, politics, or economy, but civilization. Another factor leading to the clash of civilizationsis the ever-shrinking world, which ultimately increases the intensity of interaction (Huntington, 1993: 26 and generates friction between cultures and civilizations. In addition, economic modernization, technology, and social changes have uprooted societies from their local identities and weakened the nation state as their source of cultural identity. In these conditions, religions have often showed up as sources of cultural identity. When religion is used as the source of social identity, and considered to be of the utmost importance in their lives, religions usually show fundamentalist traits and ultimately gives rise to fundamentalism. This, in turn, creates exclusivism, extremism, radicalism, and terrorism.

According to Huntington (1993: 27), another reason for the clash of civilizations is the rise of a certain awareness generated by intense inter-civilization relations. The rise of anti-Western, anti-immigrant, and anti-Islam sentiments is the actual manifestation of the rise of this awareness. Huntington also emphasizes that the different religious characteristics of civilizations, makethe acculturation process more difficult than their different political, social, and economic characteristics. According to Huntington, you can be half French and half-Arab, but it is difficult to be half-Muslim and halfCatholic. For Huntington, political, social, and economic differences are more open to compromise than differences of religion.

Nevertheless, within the context of populism theory, the clash of civilizations concept is sharply criticized, arguing that Huntington is unfairly prejudiced towards the threat of Islam - especially militant Islamto the West Huntington (1996) encouraged the West to put greater emphasis on Islam, as among the existing great civilizations, only Islam has the potential to disrupt Western civilization. According to Huntington, there is a need to differentiate between Islam in general and militant Islam. Militant Islam, including terrorist organizations and Islamic countries that keep developing nuclear weapons, is a real threat to the West. The conflict between the West and Islam is a real conflict that requires special attention from the Western countries (Huntington, 1996: 255).

The clash of civilizations concept, and its positioning of Western and Arab-Islamic civilization must be developed further according to the variables that can be used to analyze the relations between them. Especially within this context, the rise of populism is a better approach to analyze Arab and Western cultural relations.

This article discusses the relation between Arab culture and Western culture in the spectrum of the rise of populism in various countries, both in Western countries and in a number of countries on the Arabian Peninsula. The problems discussed in this study are the impact of the rise of populism on the perspective of Arab culture towards the West, and the West towards Arab culture? Regarding this problem, the study focuses on a number of issues that accompanies the rise of populism, namely the issue of anti-immigrantion, xenophobia, extremism, radicalism, anti-multiculturalism, and anti-globalization.

This study using the method of content analysis and text draws upon a number of sources on the relationship between Arab and Western cultures, especially with regard to the theme of the rise of populism in the two cultural regions. The sources of research data include books, journal articles, and information in the mass media.

\section{THE RISE OF POPULISM}

Populism is not a new thing. The term was introduced in 1967 by Ghita Ionescu, Isaiah Berlin, Ernest Gellner, Alain Touraine, Franco Venturi, and Hugh Seton-Waston (Ghergina and Miscoiu, 2013: 2). It was first used as an analytical tool in social sciences, particularly as several Third World countries experienced authoritarianism during their political integration and proved useful for phenomenological studies and trend analysis in the development of pluralism in United States. However, only in the 2000s did this new term enter the spotlight of social science and political commentary (Panizza, 2005; Bale et al., 2011; Mudde, 2004; Berezin, 2013). It has been used for a range of purposes and disciplines: politics, culture, economy, social studies, and discourse (Weyland, 2001: 1). It has also been used for analysis with various theoretical perspectives - structuralism, poststructuralism, modernization theory, social movement theory, political party theory, political psychology, political economy, and theory of democracy (Acemoglu et al., 2011; Canovan, 2002; Hawkins, 2009; Goodliffe, 2012; Postel, 2007).

When first coined, populism "seemingly" had conflicting meanings, as identified by Isaiah Berlin (1968: 172-173). He identified several meanings of populism: the idealization or sacralization of people; statism; emphasis on the extraordinary quality of leadership; xenophobia; racism; anti-Semitism; promoting an organic society 
image with cultural, social, and economic harmony; using conspiracy theories intensively and promoting apocalyptic views; affinity towards religion and nostalgia of the past; anti-elitism and anti-mainstreamism.

Among the meanings of populism identified by Berlin, xenophobia, racism, and anti-Semitism, as well as promoting the image of an organic society, are considered relevant to "the rise of populism" in this study. This is also in-line with an argument made by Hans-Georg Betz (1994:4). He argues that most right-wing radical populist parties have radical views because of their rejection of mainstream political, social, and cultural systems, as well as advocacy for individual effort, free market, and the drastic reduction of state involvement, even though they never openly question the legitimacy of democracy as a political system. According to Betz, these parties are grouped as right wing because, firstly, they reject equality among individuals and society well as the public policy to promote it. Secondly, they reject the integration of marginal social groups. Thirdly, they have an affinity for xenophobia, racism, and anti-Semitism.

The same idea was confirmed by Ronald F. Inglehart and Pippa Norris (2016: 7), who argued that, populism usually emphasizes nativism or xenophobic nationalism, which assumes that members of society must be homogeneous, and the state must exclude people from other countries or cultures. Populism prefers monoculturalism over multiculturalism, national interests over international relations, and isolationism over open society, because otherwise society can open the floodgates to foreign migrants, ideas, labor, and capital. They prefer traditionalism to progressive and liberal social values.

Populism also has several variants, depending on the context of its surrounding culture, politics, society, and geography. First, populism is spread widely, found in Western Europe, North America, Latin America, Eastern Europe, Russia, and Africa. According to Mudde and Kaltwasser (2012), populism is related to the growth of democracy in Eastern Europe, Western Europe, Canada and Latin America. Second, populist movements are found and have thrived through much of recorded history. In a study conducted by Noam Gidron and Bart Bonikowski (2014: 4), it is argued that scholars differentiate between the farmer movements in Russia and United States at the end of 19th century, later movements in the mid20th century, and the current rise of populism in Europe, United Stated, and Latin America. Third, populism also thrives in several ideologies. Populism as an ultra-right wing exclusive ideology began in Europe in the 1980s, "targeting" immigrants and minorities (Ignazi, 2003) as its victims. Meanwhile, in Latin America populism is an inclusive ideology that seeks to develop a pluralistic and multiethnic society (Madrid, 2008).

As an ideology, populism embraces valuesthat represent a specific cultural stream, that is. nativismand positions them against the values of cosmopolitan liberal ideology. In nativism, populism is a political and cultural expression marked by (i) anti-mainstream tendencies; represents marginal communities and cultures; (ii) political and cultural authority, with emphasis on charismatic leadership; and (iii) strong in-group feelings, exploiting the slogan 'us against them' and dividing people based on their social class, race, religion, etc. On the opposite side, cosmopolitanism is derived from the Greek word 'kosmopolites', which means citizens of the world' and refers to the idea that humans interact with in one world community, rather than solely in a national community. Cosmopolitan values emphasize the open boundaries among nations, the sharing of multicultural values, the recognition of human diversity and life style, openness, and inclusiveness (Inglehart and Norris, 2016: 7).

Populism, as an ideology, has become the basis of several right wing political parties in European countries. In this context, populism usually polarizes communities into two categories: commoners and political elites. Cas Mudde (2004: 543) refers to commoners as 'the pure people' and elites as 'the corrupt elite'; as such, the political activities of populist parties are claimed to stand for the common people. In Western Europe, populism is generally associated with right wing politics - particularly the radical right, the far right, and the extreme right. However, in Latin America, Eastern Europe, and Asia, populism is often associated with left wing economic policies. In the economic sector, right wing parties such as the Liberal, Conservative, and Christian Democratic Parties, especially in Western Europe, support free markets, individual property rights, reduced state roles, deregulation, and low taxes. On the other hand, political parties such as the Communist, Socialist, and Social Democratic Parties in Latin America, Eastern Europe, and Asia are left-wing, supporting state management of the economy, economic re-distribution through progressive taxation, and the state provision of welfare and public service. Meanwhile, Kazin (1995) shows that populism in America is based on four pillars. The first is Americanism, the view that the United States of America is a unique country, with its people being equals in a self-governing republic. Second, Americans are seen as productive people of good will situated between the corrupt elites on one side and poor communities on the other side. Third, elites are framed as the everlasting antithesis of 
the people: condescending, prodigal, lousy, manipulative, intellectuals, and dependent on other people's work. Fourth, the actors of American populism share a strong belief about ideas such as crusades and the need to defeat one's opponent.

In the Arab world, populism also exists, albeit with different characteristics and orientations. Referring to Hollingworth (2015: 1), the countries constituting the Arab world are Egypt, Iraq, Syria, Lebanon, Jordan, Saudi Arabia, and Yemen. Altogether, these Arab countries cover 830,000 square miles. Within these countries, populism is best known as Islamic populism, rather than Arab populism (Hadiz, 2017: 3). This is because of the ideological orientation in the Arab worldis more religious than nationalist. According to Hadiz (2017), populism in these countries has undergone orientation and ideological shifts; Arab contemporary populism is known as new Islamic populism. Hadiz (2017: 1) has said that traditional Islamic populism is based on the interests of traditional petty bourgeois, consisting of urban traders, small commodity producers, and village elites. New Islamic populism, meanwhile, is formed from an alliance of very different elements: marginalized groups from the bourgeoisie; ambitious and educated members of the urban middle class who are still trapped lower down in the social hierarchy;and the urban poor, many of whom have migrated to seek better education, work, and livelihood.

Hadiz (2013: 3) continues that 'new Islamic populism' has a higher hierarchy in society, because it has succeeded in attracting the urban middle class and other bourgeois, while the 'old Islamic populism' is seen as a petty bourgeois movement. Proponents of 'new Islamic populism' tend to be led by educated professionals, or successful businessmen.

However, populism in Arab countriesis less prominent than populism in Europe. It is not as popular as extremism, radicalism, and terrorism, which are usually connected to fundamentalist Islamic organizations in these countries. In reality, populism in Arab has not yet developed into mass movements such as those found in Europe or America, which has given rise to the ideas of 'a populist era' or 'a populist Zeitgeist' (Mudde 2004).

Nonetheless, a certain rise in populism can be seen in countries such as in Egypt. In recent years, three types of populism have emerged in Egypt. The first is a religious movement, spread by such political religious group as Ikhwanul Muslimin and Salafi, who claim that they are pure religious champions challenging the corrupt secular elites. They see Egyptians as traditionalists, religious and conservative, who seek to apply the teachings of religion in all aspects of life. They also blame Egypt's current situation on secular elites, whom they consider more loyal to religious minorities and foreign religions.

The second is socialist populism, a concept that can be traced to its intellectual inception in early 20th century, and politically can be linked to the Nasser regime (1950s-1960s). Nasser's socialist and populist regime persecuted pre-independence political and economic elites, nationalized and seized major industries, and built a one-party state that mobilized the common people against the elites to support his socialist policies. In Egypt, people follow the ideology of strong leadership, which controls the masses, represses the elites, and redistributes wealth through subsidies and public works. Even after the January 2011 revolution, socialist populism remains alive and thriving. Economic elites are often portrayed as corrupt, neo-liberal, loyal to the West, and international monetary organizations, and therefore unpatriotic. Owing to the lack of well-developed political partiesor programs in Egypt, people think that their economic problems can be solved by radical action such as confiscating the assets of big businesses, nationalizing major industries, increasing taxes, and giving subsidies.

The third is religious and economic populism, an ideology found in grass roots movements that have been forming in Egypt for decades. They emerged as a reaction to the widespread economic inequalities and political persecutions that occurred during Egypt's authoritarian regimes. They are widespread,andhave existed for several years as the legacy of tyrants (https://www.alaraby.co.uk/ english/comment/2017/8/23/tyranny-grants-populismnew-life-in-egypt).

Conversely, the rise of populism in Western countries is marked by the rise of ultra-right political parties in Europe, Brexit proponents winning a referendum, Donald Trump winning the 2016 American presidential election, and Marine Le Pen reaching the second round in France's 2017 election. According to Inglehart and Norris (2016: 7), rise of populism is also seen in racial sentiment, intolerance, anti-multiculturalism, isolationism, mistrust of foreigners, misogyny, and nostalgia for a glorious past and traditional sexual values, as well as a tendency to prefer strong leadership, offensive political styles, and anti-Muslim rhetoric.

The rise of populism around the world is propelled by two main factors: economic inequality and cultural backlash (Inglehart and Norris, 2016: 9). Economic inequality is mainly caused by globalization and the development of information and communication technology. Globalization has caused a shift of employment opportunities from the industrial centers 
in Western Europe and North America to Asia, Latin America, and Africa. Another cause of populism's rise in the Western world, as emphasized by Hans-Georg Betz (1994: 86), is the fear of losing jobs to immigrants, as well as many companiesmoving from Western countries to Asia and Africa.

However, the theory that economic inequality is the cause of populism is not very strong, according to Inglehart and Norris (2016: 9), as several surveys have shown that support for populism does not correlate with the unemployment rate, household income, or employment status. If the theory of economic inequality as the main factor driving populism were true, why has the rise of populism not come from leftist parties, whose ideology is oriented toward economic inequality and social class?

The most appropriate thesis to explain the rise of populism, thus, is cultural backlash. Since the era of modernism and the rise of humanism, Western society has experienced changes in its perception of human values, feminism, multiculturalism, and internationalism, and been marked by increased support for minorities, especially LGBT, racial minorities, and immigrants. These values are held by cosmopolitan younger people, often part of the middle class, but members of older generations perceive these values as threatening the culture and values they have held for decades. The thesis of cultural backlash can be used to explain why American voters saw Donald Trump as leading a brave and firm movement againstgay rights, immigrants, and multiculturalism. The thesis of cultural backlash can be also used to explain why pro-Brexit voters won the 2016 British referendum. For populistsin Britain - especially among older generation (Inglehart and Norris, 2016: 26) - the European Union is seen as a power that has eroded Britain's economic, political, and military power. Through the cultural backlash thesis, we can also see why populistsin several Western countries reject immigrants, whome they perceive as the major source of cultural clashes. They also believe that immigrant culture has become a threat to European cultural values.

\section{THE RISE OF POPULISM AND ARAB- WESTERN RELATIONS}

Data and information about the impact of the rise of the wave of populism on the relations of Arab-West culture in this study were obtained from several literary sources, books, journal articles, mass media, and social media. The rise of populism and its effects on Arab and Western cultures, as well as the relations between these cultures, can be seen in the rise of the following attitudes: xenophobia, anti-immigrant rhetoric, extremism, radicalism, anti-multiculturalism, and anti-globalization.

\section{Xenophobia and Anti-Immigrant Rhetoric}

The rise of populism has strengthened xenophobia, or the irrational fear of foreign people and culture. This sentiment is presently thriving, both in the West and in Arabia. The irrational fear of foreign people in the West is rooted not only in the threat of lost jobs or economic welfare, but also in the fear that traditional Western values and culture are being eroded by the influx of foreign migrants and culture in several parts of Europe and America. These fearsstem from the abundant supply of cheap labor from immigrants, which has promoted borderless labor mobilization as a direct consequence of globalization.

This cheap labor, as a threat to Western society, comes mostly from Arab immigrants who have come to Europe as refugees from the protracted wars in Iraq, Syria, Afghanistan, and Yemen. These people have endured such suffering that they have chosen to migrate, and are willing to accept low wages to ensure their continued survival and security. The influx of Arab immigrants to Europe and America has generated xenophobia, the seeds of which were sownfrom the beginning of globalization.

In Western societies that have long enjoyed the benefits of industrialization, modernization, and economic and social welfare, the arrival of Arab immigrants is seen as direct a threat to happiness and welfare. This situation has been exacerbated by the stagnant economies of several European countries and America. The economies of Greece, Spain, Italy, and Portugal nearly collapsed, and these countries were bailed out by other members of the European Union, which likewise were seeing little economic growth. According to Hans-Georg Betz (1994), this fear of foreigners, particularly Arab immigrants, has expedited the rise of populist right-wing parties. According to Betz this would suggest that the rise of radical right-wing populism is largely a result of the xenophobia that has emerged as immigrants and refugees have become increasingly visible in Western Europe (Betz, 1994: 67).

Unlike in Western society, in Arab society xenophobia is caused mostly by ideological and religious issues. They worry that capitalism and Western liberalism will have detrimental effects on Islam. Even though several Arab countries are experiencing rampant economic problems and high unemployment rates, they do not see Western people as threatening their economic activities. 
In Arab society, there is a fear of Western culture itself, which is seen by some as secular, immoral, and hedonistic, with alcoholism and drug abuse. This culture, seen by some Arab people as the source of the modern world's corruption, is considered even more frightening because it has attracted younger Arabs. The spread of Western culture, supported by information and communication technology and other conventional mass media, has posed a real threat towards Arab culture and its Islamic values.

Although there are differences in the rise of xenophobia in the West and in Arabia, culture variables seem to be a shared factor. Each culture perceives the other as a threat. They all worry about their culture being eroded and marginalized by foreign culture. It is not surprising to see such xenophobia narrated in variousliterature in the West and in Arabia.

According to Ray Taras (2008), xenophobia has become a transnational phenomenon. Xenophobia, stereotyping, antipathy, and bias have colored the attitudes and behaviors of societies in many parts of the world. Even in Western Europe, according to Taras, Islamophobic narration is on the rise in literature. Xenophobia and cynicism against Muslims and Arabs can be found, for example, in the novel Platform by Michel Houellebecq. In the novel, it is written, "Islam was born in the middle of the desert, in the middle of scorpions, camels, and ferocious animals of all types. You know what I call Muslims? The scum of the Sahara...Islam could not be born except in a stupid desert among filthy Bedouins who had nothing else to do but - pardon me-bugger camels (Houellebecq, 2003: 243-244). Elsewhere, it is written, "the Muslim system was condemned: capitalism would be stronger. Already young Arabs dream of nothing else but sexual consumption"(Houellebecq, 2003: 339).

Xenophobia, which is common in every community and culture, is reinforced by the social, economic, political, and security dynamics in many parts of the world. Prolonged conflict in several Arab countries has caused millions of people to flee to safer countries, including in the West. The migration of Arab refugees to the West has been used by extreme right populist parties to gather votes, who have exploited the fear and anxiety regarding social disruption, security threats, and terrorism. Almost all extreme right populist parties in Europe have complained about immigration (Brubaker, 2001; Ivarsflaten, 2008) and have often used anti-Arab narration in their campaigns.

Donald Trump, a populist leader, for example, five years before being declared a Republican United States presidential candidate, in a session with David Letterman on NBC (9/4/2010) and asked about "Does this, in fact, suggest that we are officially at war with Muslims?" Trump then answered, "Well somebody knocked down the World Trade Center... somebody's blowing us up. Somebody's blowing up buildings, and somebody's doing lots of bad stuff." On December 3, 2011, in a Fox News interview with Bill O'Reilly, Trump was asked about whether there was a problem with Muslims in the world? Trump replied, “Absolutely. I mean, I don't notice Swedish people knocking down the World Trade Center. There is a Muslim problem in the world, and you know it and I know it.'In an interview with $\mathrm{CBN}$, Trump delivered a statement he made in his interview with Bill O'Reilly a step further, saying that the Koran "teaches some very negative vibe [sic] ... when you look at people blowing up in the street in some countries in the Middle East ... when you look at 250 people who die in a supermarket while shopping... there's a lot of hatred there someplace." (CBN, 4/12/2011). In an interview on Fox News (12/13/2015), Trump was asked whether all Muslims should be banned from the United States? Trump answered 'There's a sickness. They're sick people. There's a sickness going on. There's a group of people that is very sick. And we have to figure out the answer. And the Muslims can help us figure out the answer."

Through CNN (3/9/2016), Trump even said that "I think Islam hates us. There's something there thatthere's a tremendous hatred there. There's a tremendous hatred. We have to get to the bottom of it. There's an unbelievable hatred of us." Trump's statement was then repeated again when Trump joined Fox News host Chris Wallace on "Fox News Sunday," (3/13/2016) and, again saying that "Islam hates us," he suggested that there is a "tremendous" amount of hatred on the part of Muslims for the United States. Citing the Pew Research poll, Trump said that 27 percent of Muslims around the world are "very militant." This statement was repeated when Trump appeared on Bloomberg TV (3/23/2016), where Trump said that people "...have to respect us. They do not respect us at all. And frankly, they don't respect a lot of the things that are happening throughout not only our country, but they don't respect other things."

Trump's strong statements against Muslims were initially thought to be only to gain support from US voters. However, just eight days after he was inaugurated as president of the United States, Trump has signed an executive order banning refugees and Muslim-majority citizens, namely Iraq, Syria, Iran, Libya, Somalia, Sudan and Yemen for a period of 90 days. The ban was imposed immediately in the afternoon, which of course caused chaos and confusion at airports throughout the United 
States and caused many people to be detained. The fact that someone like Donald Trump was later elected as the leader of a superpower is proof that the rise of populism in the Western world has implications for the flourishing of xenophobia and anti-immigrants, and these two issues always related to the Muslim community, particularly from Iraq, Syria, Iran, Libya, Somalia, Sudan and Yemen.

In the West, support for extreme right populist parties and their anti-immigrant campaigns gains increasing support every day. The success of Brexit in Britain, the increased popularity of Geert Wilders, and the success of Marine Le Penare proof of this support. Previously, extreme right populist parties in Europe, such as Lega Nord (Italy), Freedom Party (Austria), People's Party (Swiss), Sweden Democrats (Sweden), Progress Party (Norway), Danish People's Party (Denmark), and True Finns (Finland) have also gained political support by campaigning on anti-immigration platforms (Eatwell, 2000; Kehrberg, 2007). Research by Martins (2012: 1) identified the success of extreme right populist parties in Western Europe. The Sweden Democrats or Swedish Democrats (Swedish: Sverige demokraterna, SD) in Sweden, which has positioned immigration as the biggest threat to Swedish people since World War II, gained 20 seats in the 2010 parliamentary election. Lega Nord in Italy gained 20 seats in parliament in the 2008 election. The Progress Party gained 23 percent of the vote in 2009 Norway general election. In 2011, the Danish People's Party gained 22 seats $(12.3 \%)$ in the parliamentary election in Denmark. Successful results were also had by two populist parties in Europe: in 2011, True Finns (Finland) gained 39 seats (19.1\%), and the People's Party (Swiss) gained 54 seats (26.6\%). Similar results were also achieved by the Dutch Party of Freedom (PVV) in Netherlands. it gained 5 seats in the 2012 election, a number that increased to 20 seats in 2017.

Anti-immigrant attitudes in Europe are not only evident in the political gains made by populist right wing parties, but also in violence against immigrants. In May 2008, a group of Neo-Nazis in Italy attacked and killed several Chinese, Indian, and Bangladesh immigrants. In 2010, a populist and anti-immigrant male shot dozens of immigrants in Sweden in 2011, an anti-Muslim and antimulticulturalism male conducted a double terror attack in Norway (Martins, 2012: 3-4).

Statistical studies conducted by the European Union Agency for Fundamental Rights (EUAFR) have shown that violence and criminal acts against immigrants in Europe are increasing. It is clear that the rise of populism has had a serious impact on the reception give to foreigners, both in the West and in the Arab world.

\section{Extreme and Radical}

The basic characteristis of populism are extreme and radical viewpoints. Ignazi (2003) labels right wing parties in Europe as 'extreme right parties', while Betz (1993) labels them 'radical right-wing populism'. The extreme rightis opposed to mainstream groups. While mainstream society shows tolerance, openness, inclusiveness, and hospitability towards foreigners, populism shows intolerance, closed mindedness, and exclusiveness, especially towards immigrants. By exploiting religious, cultural, and economic issues, such groupstry to incite prejudice against everything linked to mainstream values.

Extreme populism is shown in more extreme acts, radical attitudes and behaviors. They tend to use violence to reach their ideals. Populist groups often act violently against groups they dislike, especially immigrants, minorities, and other communities with different views. Several individuals from such groups have also been involved in cases ofviolence, including assault and murder.

Religious issues are often used as tools of expression in populist extremist groups. In the West, populism positions Islam as a threat against Christianity. Western society, deeply affected by the terror attacks of radical Islamic group, has been incited to develop stereotypical views about Islam, which is perceived by populists in the West as consisting of warlike people who are terrifying and terrorizing.

Even before the 21 st century, when populism was not yet perceived as a threat, the seeds of Islamophobia were already sown in Western culture. The Western and Arab worlds were seen as opposing cultural entities. Arabic and Islamic cultural values were deemed incompatible with Western cultural values, as quoted in Haider (1993: 92-93), "Islamic social order is opposed to our Western values". At the end of the 1980 s, the perception that Islam was a threat to Western culture became increasingly prominent (Betz, 1994: 94). For example, a 1990 survey showed that 71 percent of the French population associated Islam with fanaticism. The same survey showed that only 43 percent of French people would accept the building of a mosque in their neighborhood. A 1991 survey in Denmark showed that 55 percent of that country's population would reject the building of big mosques in Denmark (Betz, 1994: 94). The European Values Study in 2008 showed that the victims of the most intolerant acts in Western Europe were Muslims (Rubin, et al., 2014: 11-14). This survey also showed that intolerance toward Muslims in many European countries has increased. 
Several cultural artifacts have contributed to negative attitudes towards Arabic and Islamic cultures. A short film titled Innocence of Muslims, produced by Nakoula Basseley Nakoula in 2012, portrays anegative view of Muhammad. Theo van Gogh, a Dutch movie producer, actor, and columnist, exhibited a critical attitude of Arab-Islam in his movie Submission (Guiora, 2014: 154). Fitna, produced by Geert Wilders, is another Western cultural product that exhibits anti-Arab and antiIslamic attitudes. According to Fekete (2012), Fitnawritten by Geert Wilders himself-sought toshow the world that "Islam and the Koran are part of a fascist ideology that wants to kill everything we stand for in a modern Western democracy".

Other Western cultural products that have created conflict with Arabic and Islamic culture are caricatures in mass media. In one 2002 issue, the weekly German magazine Der Spiegel published a "caricature" of Muhammad. In 2005, one episode of the Morgan Spurlock series Muslims and America showed caricatures of Muhammad. That same year, the Dutch daily newspaper, Jyllands-Posten also published degrading caricatures of Muhammad. In 2007, Lars Vilk, a Swedish artist produced a cartoon degrading Muhammad. Of Western caricatures, the most shocking to the Arab and Islamic world was a series of cartoons mocking Muhammad that were published in several editions of the magazine Charlie Hebdo.

Strong reactions against these cultural products, seen as degrading and mocking to Islam and its prophet, have come from Muslim communities around the world. An extreme reaction was that of Mohammed Bouyeri, a radical Muslim who shot Theo van Gogh eight times on 2 November 2004. Other violence targeted the editors and staff of Charlie Hebdo. The offices of this magazine were attacked on 7 January 2015, 12 staff members were killed, including editor Stephane Charbonnier (Khan, 2014: 49). Before that, in September 2012 demonstrations against the short film Innocence of Muslims were held in many Middle-East countries (Giora, 2014: 127).

\section{Anti-Multiculturalism}

Populism in Europe has serious implications for the doctrine of multiculturalism that has become the sociocultural foundation of several European countries. Almost all parties that are based on populist ideology have rejected the idea of multiculturalism as the basis for Western society. Haider (1993: 94) said that "radical rightwing populist parties... strongly opposed 'the utopia of a multicultural society",.
As populism has gained traction in Europe, several political leaders in Britain, Germany, and other European countries admitted that multiculturalism had failed as the foundation of European socio-cultural life. They said that the doctrine of multiculturalism had failed to overcome right wing radicalization and religious-based terrorism. Some Western countries admitted that they had been unable to impede the backlash against other cultures and failed to manifest a vision where every group and culture can play a part.

The rise of populism has even created the view that multiculturalism encourages different cultural groups to live separately, and sows values opposite to those imlicit in equality, democracy, rule of law, human rights, and respect for human dignity regardless of race, ethnicity, religion, and political views. These European values have enabled the rise of many political views, including anti-multicultural right wing populism. Several European leaders have called for firm action against extremist groups. Bothultra-right nationalist and Islamic radical extremist groups are perceived as threatening the Western world's multi-ethnic, multi-religious, and multicultural society.

Multiculturalism in Europe can be understood in different ways, depending on one's point of view (i.e. it is multi-discursive). In multicultural Europe, each individual has the ability to interact and transact even when coming from a different culture, based on his or her accommodative, associative, adaptable, and flexible nature as a human being. This existing view, which serves as the foundation for modern European society, indicates that diverse cultures consist of many elements and have their virtuous values. In building a strong socio-cultural order in Europe, these values can be used as binding elements in the interactions of individuals and social groups. Only by limiting cultural clashes can a plural European society can be formed, based on the principles of mutual respect and coexistence.

Multiculturalism, as the cultural basis of several European countries, cannot be equated with the concept of ethnic or cultural diversity, both of which are characteristics of plural society, as multiculturalism emphasizes the equality of culture. Multiculturalism in Europe also explains the supporting ideas of this ideology: politics and democracy, justice and rule of law, equal employment, human rights, local community and minority rights, and ethical and moral principles. These values are also are targeted by ultra-right nationalist proponents.

Proponents of populism reject the basic belief of multiculturalism, which demands the understanding, 
respect, and appreciation of other cultures. Western multiculturalism, which supports the appreciation of other cultures, does not imply agreement with all aspects of culture, but tries to see how other cultures can express values among themselves. They also reject European multiculturalism, which emphasizes the transaction of knowledge and experience among members of society in interpreting their own worldview.

\section{Anti-Globalization}

Populists in the West reject globalization because it has caused many manufacturing industries to move to Asian, Latin American, and African countries. As a result, the number of jobs in the West has decreased and the unemployment rate has increased. On the contrary, populism in Arab countries sees globalization as a means to spread the ideas of capitalism and liberalism, which are against their ideology. From a cultural aspect, globalization both for populists in the Western and Arab worlds - is an agent for spreading foreign cultural values that threaten their cultural identity.

According to Scholte (2000), there are at least five categories that populists consider to cause increased migration, higher mobility of goods and service, and threats to their culture, identity, jobs, and security:(i) internalization, (ii) liberalization, (iii) universalization, (iv) Westernization, especially Americanization, and (v) the disappearance of territorial borders (Scholte, 2000: 17). Western populists consider globalization to be the cause of immigration (especially from the Middle East and Africa), which makes them fear that they will lose their jobs; while the populists in the Arab world tend to see globalization as Westernization and Americanization. As such, both populists in the Western and Arab worlds are against globalization.

For both the concept of globalization is inherently full of contradiction. On one hand, globalization exists because of instantaneous communication, but on the other hand its promise of justice and democracy is never realized. Those taking a populist view tend to see globalization as a concept with destructive potential, in which new values clash with old values. As a result, globalization has a winning side and a losing side. The fast rhythm of globalization is set by the global economic power houses, which will ultimately create a new dichotomy in multilateral relations, with certain countries being central and certain countries being peripheral. The countries that cannot follow the rhythm of globalization will be categorized 'globally' as 'primitive'.

Populists reject the general notion that the poverty rates in developing countries will decline significantly with globalization. For them, globalization poses a serious risk to developing countries, as it increases socio-economic disparity on many levels and promotes cultural uniformity. Anti-foreign culture populists believe that information and communications technology may improve economic growth and social development, either horizontally or vertically. However, they also worry about the promotion of cultural uniformity through the popular culture spread by globalization.

Populist thinkers also discuss the paradox of globalization as related to the concept of universality and particularization. On one hand, globalization pushes global society towards one world system, but on the other handthe unique characteristics of culture and nation also promote exclusivism. This contradiction of homogeneity and diversity is another paradox of globalization. Homogeneity means that the progress of humans, societies, and nations towards the integration of cultural and social systems, which in the context of globalization is promoted by popular culture in mass media and information and communication technology. For some people, globalization means increased homogeneity of global society and culture. On the other hand, globalization also promotes diverse cultures in society.

As part of a community that rejects globalization, populists often identify themselves as part of a Global Justice Movement. For populists in the Arab world, globalization is a negative phenomenon, as it is just another form of Western colonization that forces specific interests through the promotion of cultural homogenization and consumptive behavior. For them, globalization-particularly the global economy and trade has practically destroyed the environment, local cultures, labor rights, national sovereignty, and third world countries. They see globalization as a pretext for promoting neoliberalism, which according to Mansour Fakih (2003) consists of several hidden myths: (i) free trade will guarantee cheap food and avoid famine, when in reality free trade increases food prices; (ii) the World Trade Organization (WTO) and the Trade Negotiations Committee (TNC) will produce safe food, when in reality the overuse of pesticides and Genetic Modified Organism (GMO) have harmed human health and the ecological balance; (iii) women will benefit from free trade, when in reality women farmers are excluded as producers or consumers; (iv) patents and intellectual rights will protect innovation and knowledge, when in reality, patents slow down the transfer of technology and make technology more expensive; and (v) free trade in the food sector will 
benefit consumers because of cheaper prices and more choices, when in reality it threatens food security in third world countries.

The anti-globalization characteristic of populism shapes its views regarding the mobility of goods, services, and humans across countries. The mobility of goods, services, and humans is not seen as having the potential to improve welfare, but is perceivedas a threat to cultural integrity and traditional values.

\section{CONCLUSION}

Populism in the Arab and Western worlds has several common characteristics: xenophobia, isolation, intolerance, hostility towards strangers, extremism, radicalism, anti-multiculturalism, anti-globalization, and resistance against the mainstream. While anti-immigrant and anti-Islamic views are characteristics of populism in the West. Meanwhile, in the Arab world populism tends to be anti-capitalist and anti-liberalist. The rise of populism has is influencing Arab and Western cultures, as well as the relations between these societies. Postcolonial Western culture promoted tolerance, openness, inclusiveness, and hospitability, including towards immigrants; however, after the rise of populism, the Western worldview has changed significantly and is more closed to the outside world, foreigners, immigrants, and Islam. Western culture, as depicted in the rise of populism, has become intolerant, closed, xenophobic, and lost faith in multiculturalism. Meanwhile, the Arab world, which initially had limited contact with the ideas of humanism and multiculturalism, has be come more anti-Western, anti-capitalist, and anti-liberal.

\section{REFERENCES}

Acemoglu, Daron, Georgy Egorov, and Konstantin Sonin (2011).'A Political Theory of Populism, 'NBER Working Papers 17306, National Bureau of Economic Research.

Arief, Sritua, and Adi Sasono (1984). Indonesia: Ketergantungan dan Keterbelakangan. Jakarta: Sinar Harapan.

Berezin, Mabel (2013). The Normalization of the Right in Post-Security Europe. Armin Schaefer and Wolfgang Streeck (eds.), Politics in an Age of Austerity. Cambridge: Polity Press.

Berlin, Isaiah et. al. (1968). To Define Populism. Government and Opposition, 3(2), 137-180.

Betz, Hans-Georg (1994). Radical Right-Wing Populism in Western Europe. London: The Macmillan Press.

Bove, Jose (ed.) (2004). The Movement of Movements: A
Reader. London-New York: Verso.

Brubaker, Rogers (2001). The Return of Assimilation? Changing Perspectives on Immigration and its Sequels in France, Germany, and the United States. Ethnic and Racial Studies, 24, 531-548.

Canovan, Margaret (2002). Taking Politics to the People: Populism as the Ideology of Democracy. Meny, Yves and Yves Surel (eds.), Democracies and the Populist Challenge. New York: Palgrave, pp. 25-44.

Carter, Elisabeth (2005). The Extreme Right in Western Europe: Success or Failure? Manchester: Manchester University Press.

Colas, A. (2004). The Re-Invention of Populism: Islamist Responses to Capitalist Development in the Contemporary Maghreb. Historical Materialism, 12, 231-260.

Eatwell, Roger (2000). The Rebirth of the 'Extreme Right' in Western Europe? Parliamentary Affairs, 53, 407-425.

Fakih, Mansour (2003). Bebas dari Neoliberalisme. Yogyakarta: Insist Pers.

Fekete, Liz (2012). The Muslim Conspiracy Theory and the Oslo Massacre. Race Class, 53(3), 30-47.

Friedman, Thomas L. (2000). Lexus and the Olive Tree. USA: Farrar, Straus and Giroux.

Gherghina, Sergiu, and Sergiu Mişcoiu (2013). Contemporary Populism: A Controversial Concept and Its Diverse Forms. Cambridge: Cambridge Scholars Publishing.

Gidron, Noam, and Bart Bonikowski (2014). Varieties of Populism: Literature Review and Research Agenda. Cambridge: Weatherhead Center for International Affairs, Harvard University.

Goodliffe, Gabriel (2012). The Resurgence of the Radical Right in France. Cambridge: Cambridge University Press.

Gracia, Jorge J.E. (2002). Globalization, Philosophy, and Latin America. M. Sáenz (ed.), Latin American Perspectives on Globalization: Ethics, Politics, and Alternative Visions. Lenham: Rowman \& Littlefield Publishers.

Guiora, Amos N. (2014). Tolerating Intolerance: The Price of Protecting Extremism. Oxford: Oxford University Press.

Hadiz, Vedi R. (2013). A New Islamic Populism and the Contradictions of Development. Journal of Contemporary Asia, 2013. http://dx.doi.org/10.108 0/00472336.2013.832790

Hadiz, Vedi R. (2011). The New Islamic Populism. Global Dialogue, 2(2).

Haider, J. (1993). Die Freiheit, Die ich Meine. FrankfurtBerlin: Ullstein.

Hawkins, Kirk A. (2009). 'Is Chavez Populist?: Measuring Populist Discourse in Comparative Perspective', Comparative Political Studies, 42.

Hawkins, Kirk A. (2010). Venezuela's Chavismo and 
Populism in Comparative Perspective. Cambridge: Cambridge University Press.

Henry, M.,and S. Taylor (1997). Globalisation and National Schooling Policy in Australia. B. Lingard and P. Porter(eds.), A National Approach to Schooling in Australia: Essays on the Development of National Policies in School Education. Canberra: AustralianCollege of Education.

Hollingworth, Clare (2015). The Arabs and the West. New York: Routledge.

Houellebecq, Michel (2003). Platform. New York: Knopf. Hunter, Shireen (1998). The Future of Islam and the West: Clash of Civilizations or Peaceful Coexistence? Washington DC: Greenwood Publishing Group.

Huntington, Samuel P. (1993). The Clash of Civilizations? Foreign Affairs.

Huntington, Samuel P. (1996). The Clash of Civilizations and the Remaking of World Order. New York: Simon $\&$ Schuster.

Ignazi, Piero (2003). Extreme Right Parties in Western Europe. Oxford: Oxford University Press.

Inglehart, Ronald F., and Pippa Norris (2016). Trump, Brexit, and the Rise of Populism: Economic Have-Nots and Cultural Backlash. Harvard: Harvard Kennedy School.

Ionescu, Ghita, and Ernst Gellner, (eds.) (1969). Populism: Its Meanings and National Characteristics. New York: Macmillan.

Ivarsflaten, Elisabeth (2008). What Unites Right-Wing Populists in Western Europe? Re-Examining Grievance Mobilization Models in Seven Successful Cases. Comparative Political Studies, 41, 3-23.

Kaltwasser, Cristobal Rovira (2012). The Ambivalence of Populism: Threat and Corrective for Democracy. Democratization, 9(2), 184-208.

Kaltwasser, Cristobal Rovira (2013). The Responses of Populism to Dahl's Democratic Dilemmas, Political Studies.

Kehrberg, Jason E. (2007). Public Opinion on Immigration in Western Europe: Economics, Tolerance, and Exposure. Comparative European Politics, 5, 264261.

Khan, Aijaz Ahmad (2014). The Offensive Depictions of Prophet Muhammad (SAW) in Western Media and its Consequences. Journal of Islamic Thought and Civilization, 4(1).

Levitt, Theodore (1983). Globalization of Markets. Harvard Business Review.

Lewis, Bernard (1982). The Muslim Discovery of Europe. New York: Oxford University Press.

Madrid, R. L. (2008). The Rise of Ethnopopulism in Latin America. World Politics, 60(3), 475-508.

Martins, Nathalia De Almeida Barros (2012). AntiImmigrant Rhetoric in Western Europe: The Role of Integration Policies in Extreme Right Populism. Thesis at the Department of Political Science in the College of Sciences at the University of Central Florida, Orlando, Florida

McLuhan, Marshall, andBruce R. Powers (1992). The Global Village: Transformations in World Life and Media in the 21st Century: Communication and Society. Oxford: Oxford University Press.

Mertes, Tom (ed.) (2004). A Movement of Movements: Is Another World Really Possible? London-New York: Verso

Mudde, Cas, and Cristóbal Rovira Kaltwasser (eds.) (2012). Populism in Europe and the Americas. Cambridge: Cambridge University Press

Mudde, Cas (2004). The Populist Zeitgeist. Government and Opposition, 39(4), 542-563.

Mudde, Cas (2007). Populist Radical Right Parties in Europe. Cambridge: Cambridge University Press.

Panizza, Francisco (2005). Populism and the Mirror of Democracy. London: Verso.

Postel, Charles (2007). The Populist Vision. Oxford: Oxford University Press.

Roy, O. (2004). Globalised Islam: The Search for A New Ummah. London: Hurst.

Rubin, Jennifer, et al. (2014). Intolerance in Western Europe: Analysis of Trends and Associated Factors. Santa Monica: RAND Corporation.

Scholte, Jan Aart (2000). Globalization:A Critical Introduction. London: Palgrave.

Suárez-Orozco, Marcelo M. \& Desirée Baolian Qin-Hilliard (2004). Globalization: Culture and Education in the New Millennium. California:Regents of the University of California.

Taras, Ray (2008). Transnational Xenophobia in Europe? Literary Representations of Contemporary Fears. Language and the Scientific Imagination, 11th International Conference of ISSEI, Language Center, University of Helsinki, Finland, 28 July - 2 August 2008.

White, J. (2002). Islamist Mobilization in Turkey: A Study in Vernacular Politics. Seattle: University of Washington Press.

(https:/www.alaraby.co.uk/english/comment/2017/8/23/ tyranny-grants-populism-new-life-in-egypt).

News transcript from NBC, 9/4/2010.

News transcript from CBN, 4/12/2011.

News transcript from Fox News, 12/13/2015.

News transcript from CNN, 3/9/2016.

News transcript from Fox News Sunday, 3/13/2016.

News transcript from Bloomberg TV, 3/23/2016. 